\title{
Przedsiębiorcze kobiety Wałbrzycha w latach 2013-2020
}

\section{Enterprising women in Wałbrzych (Poland) in 2013-2020}

\begin{abstract}
Biznes każdej firmy zaczyna się i kończy na dogłębnej analizie liczb. Niezależnie od tego, czym dana firma się zajmuje, jeżeli nie umie wyciagnąć wniosków z faktów dotyczących własnej działalności i podejmuje decyzje oparte na powierzchownych informacjach lub intuicji, w ostatecznym rozrachunku zapłaci za to wysoka cenę.
\end{abstract}

B. Gates, współzałożyciel Microsoftu

Streszczenie: Celem artykułu jest zaprezentowanie przedsiębiorczych zachowań kobiet, które w latach 2013-2020 założyły w Wałbrzychu działalność gospodarczą, a także próba określenia, czy pandemia COVID-19, która rozpoczęła się w Polsce w marcu 2020 r., miała wpływ na przedsiębiorcze decyzje mieszkanek Wałbrzycha, ze szczególnym uwzględnieniem liczby i rodzajów założonych przez nie firm. Analiz dokonano na wybranych danych statystycznych pozyskanych z Głównego Urzędu Statystycznego - opartych w głównej mierze na bazie REGON i zestawieniu PKD, z wykorzystaniem raportów Państwowej Agencji Rozwoju Przedsiębiorczości. Do analiz wykorzystano metodę desc research oraz dedukcję. Na podstawie uzyskanych wyników wskazano rodzaje działalności, które cieszyły się największym zainteresowaniem wśród kobiet decydujących się na założenie własnej firmy, przy czym pandemia COVID-19 nie wpłynęła na zmianę rodzaju działalności, która we wszystkich latach objętych badaniem była niezmiennie rejestrowana najczęściej. Dzięki szczegółowej analizie danych uwidoczniono różnorodność wśród nowo powołanych kobiecych działalności gospodarczych.

Abstract: The aim of the article was to present the entrepreneurial behaviour of women who started a business in Wałbrzych (Poland) in 2013-2020, as well as an attempt to determine whether the COVID-19 pandemic, which began in Poland in March 2020, had an impact on the entrepreneurial decisions of Wałbrzych female residents, with particular emphasis on the number and types of companies established by them. The analyses were performed on selected statistical data obtained from the Central Statistical Office - based mainly on the REGON database and on the PKD statement, with the use of reports of the State Agency for Enterprise Development. The analyses were based on the desc research method and deduction. The types of activity that were most popular among women deciding to set up their own companies were indicated, while the COVID-19 pandemic did not change the type of activity, 
which in all the years covered by the study was invariably the most frequently registered. A detailed analysis of the data revealed the diversity among newly established female economic activities.

Słowa kluczowe: COVID-19; działalność gospodarcza; kobiety; miasto Wałbrzych; przedsiębiorczość

Keywords: city of Wałbrzych; COVID-19; economic activity; entrepreneurship; women

Otrzymano: 30 czerwca 2021

Received: 30 June 2021

Zaakceptowano: 26 sierpnia 2021

Accepted: 26 August 2021

\section{Sugerowana cytacja/Suggested citation:}

Buczak, A. (2021). Przedsiębiorcze kobiety Wałbrzycha w latach 2013-2020. Przedsiębiorczość Edukacja [Entrepreneurship - Education], 17(2), 121-136. https://doi.org/10.24917/20833296.172.9

\section{Wstęp}

Przedsiębiorczość, przedsiębiorczy, przedsiębiorstwo - te słowa odmieniane są przez przypadki we wszystkich krajach świata. Są to pojęcia wielopojęciowe, wielowymiarowe, wieloaspektowe, charakteryzujące różne fazy rozwoju gospodarczego. Z kolei przedsiębiorczość w potocznym, „codziennym” rozumieniu niejednokrotnie postrzegana jest jako zaradność, spryt, umiejętność pokonywania trudności i znajdowania rozwiązań, często jako przebiegłość, niekiedy jako kombinatorstwo lub umiejętność wykorzystania nadarzającej się okazji. Jako pojęcie wielowymiarowe przedsiębiorczość jest przedmiotem badań wielu dyscyplin naukowych. Uważa się ją za kluczowy czynnik wzrostu gospodarczego, poprawy konkurencyjności gospodarek, dobrobytu regionów oraz społeczności lokalnych. Celem niniejszego artykułu jest zaprezentowanie przedsiębiorczych zachowań kobiet, które w latach 2013-2020 założyły w Wałbrzychu działalność gospodarczą, a także próba określenia, czy pandemia COVID-19, która rozpoczęła się w Polsce w marcu 2020 r. (wykrycie pierwszego potwierdzonego przypadku zakażenia wirusem), miała wpływ na przedsiębiorcze decyzje mieszkanek Wałbrzycha, ze szczególnym uwzględnieniem liczby i rodzajów założonych przez nie firm. Artykuł został napisany na podstawie: autorskich badań przeprowadzonych na potrzeby rozprawy doktorskiej pt. Instytucje otoczenia biznesu a podejmowanie działalności gospodarczej przez kobiety (2019) oraz projektu badawczego pt. „Instytucje otoczenia biznesu a podejmowanie działalności gospodarczej przez kobiety w miastach na prawach powiatu województwa dolnośląskiego w czasach pandemii COVID-19” (2021), analizy wybranych danych statystycznych pozyskanych z Głównego Urzędu Statystycznego - opartych w głównej mierze na bazie REGON i zestawieniu PKD, z wykorzystaniem raportów Państwowej Agencji Rozwoju Przedsiębiorczości. Do przeprowadzenia analiz wykorzystano metodę desc research oraz dedukcję.

\section{Przedsiębiorczość w Polsce i na świecie - wybrane zagadnienia}

Szacuje się, że największy wzrost przedsiębiorczości w Polsce miał miejsce w latach 2011-2016 - potwierdzenie tego faktu można znaleźć w danych statystycznych udostępnianych m.in. przez PARP, który w Raporcie o stanie sektora małych i średnich przedsiębiorstw $w$ Polsce podaje, iż „Analiza danych na przestrzeni lat pokazuje, że liczba 
przedsiębiorstw systematycznie rośnie: w 2008 r. działało 1,79 mln firm, zaś w 2014 r. $1,84 \mathrm{mln}$, a w 2015 r. 1,91 mln. W roku 2015, w porównaniu z poprzednim rokiem, odnotowano jeden $\mathrm{z}$ najwyższych wzrostów liczby przedsiębiorstw niefinansowych w ostatnich latach - o blisko 4\%, a w okresie 2011-2015 wzrost liczby przedsiębiorstw wyniósł 7,3\%" (PARP, 2018: 8).

Od 2017 r. odnotowany został zauważalny spadek liczby osób prowadzących firmy przez okres od ponad 3 miesięcy do 3,5 lat przy relatywnie wysokim poziomie liczby osób w fazie organizacji firm (przedsięwzięcia, w których okres wypłacania wynagrodzeń jest krótszy niż 3 miesiące lub jeszcze ich nie ma). Jednocześnie wyraźnie wzrósł odsetek osób prowadzących dojrzałe firmy (za dojrzałych przedsiębiorców uznaje się osoby prowadzące biznesy, w których wynagrodzenia wypłacane są min. 42 miesiące). W 2018 r. w porównaniu z 2017 r. odsetek tych ostatnich, czyli firm dojrzałych, zwiększył się z 9,8\% do 13\% (o $32 \%$ ), a w odniesieniu do 2015 r. - o 120\%. Warto wspomnieć jeszcze o zaobserwowanym jednoczesnym spadku odsetka osób w fazie organizacji swoich firm - w porównaniu z 2017 r. (z 6,7 do 4,1\%) oraz odsetka nowych firm - o połowę (PARP, 2020: 34).

Według Krajowego Wskaźnika Uwarunkowań Przedsiębiorczości (National Entrepreneurship Context Index - NECI $)^{1}$ : „Polska, pod względem omawianego wskaźnika, zajmuje 15 miejsce wśród 22 państw Europy objętych badaniem, osiągając wynik 4,42 pkt. Natomiast, gdy pod uwagę weźmiemy wszystkie 54 gospodarki uwzględnione w badaniu GEM, to nasz kraj zajmuje 36. pozycję" (PARP, 2020: 88). Zatem koniecznym jest podejmowanie wysiłków zmierzających do poprawy warunków dla rozwoju przedsiębiorczości, by, po pierwsze, przedsiębiorczość w Polsce stale podlegała progresowi, po drugie, by podążać za gigantami Europy w tym zakresie, najwyżej notowanymi krajami: Szwajcarią i Holandią, a także Norwegią, Hiszpanią, Luksemburgiem i Niemcami. Co istotne, w ww. raporcie wskazano, że „najniższe wartości wskaźnika wśród krajów Europy dotyczą Chorwacji $(3,57)$ i Macedonii Północnej (3,84)” (PARP, 2020: 89).

W przedstawione powyżej cechy wpisuje się również węższe ujęcie przedsiębiorczości - przedsiębiorczość kobiet. Jest ona ważnym zagadnieniem, które stanowi wyzwanie dla współczesnych społeczeństw. W ostatnich czasach coraz więcej uwagi poświęca się kwestii kobiet, ich rolom nie tylko społecznym, ale też - gospodarczym. Przedsiębiorczość kobiet bezsprzecznie jest złożonym zjawiskiem, które w Polsce zaczęło się dynamicznie rozwijać po 1989 r., kiedy w wyniku przemian społeczno-gospodarczych zaczęto zamykać sfeminizowane zakłady pracy, czego skutkiem była utrata pracy przez ogromną liczbę kobiet, niemal z dnia na dzień. W tak trudnym czasie kobiety zaczęły podejmować własne działalności gospodarcze, choć często uznaje się, że działania przedsiębiorcze są domeną męską. Polska Agencja Rozwoju Przedsiębiorczości podaje, że w całym okresie transformacji przybyło relatywnie więcej kobiet pracujących na własny rachunek niż pracujących mężczyzn (PARP, 2011: 15).

Analizując literaturę przedmiotu i źródła statystyczne, zauważyć można, że przedsiębiorczość kobiet przyczynia się do rozwoju gospodarczego poprzez tworzenie nowych produktów i miejsc pracy. Kobieta - właścicielka firmy - wykazuje się cechami przedsiębiorczymi,

\footnotetext{
${ }^{1}$ Po raz pierwszy dane dotyczące wskaźnika opublikowano w raporcie Global Entrepreneurship Monitor - Global Report 2018/2019, w którym wskaźnik został wyliczony na podstawie danych z badania eksperckiego dotyczącego uwarunkowań przedsiębiorczości (National Expert Survey - NES). Wskaźnik ma pomóc w pomiarze i ocenie łatwości zakładania i rozwijania działalności gospodarczej w krajach uczestniczących w badaniu. Im wyższy wskaźnik ma dany kraj, tym lepsze panują w nim warunki do rozwoju przedsiębiorczości (PARP, 2020).
} 
które pozwalają skutecznie przełamywać społeczne bariery i aktywnie uczestniczyć w procesach gospodarczych, jest ambitna, zdeterminowana, nie podejmuje decyzji pochopnie. Warto w tym miejscu przywołać najnowszy Raport z badania Global Entrepreneurship Monitor Polska 2020, gdzie wskazano, iż: „w 2019 r. udział osób prowadzących młode firmy wśród kobiet i mężczyzn po raz pierwszy od lat był bardzo podobny - 5,7\% dla mężczyzn i 5,1\% dla kobiet, podczas gdy jeszcze w poprzedniej edycji GEM (2019) różnica na niekorzyść kobiet była bardziej wyraźna. Podobną tendencję można także zaobserwować w odniesieniu do dojrzałych firm - w 2019 r. 13\% mężczyzn i 12,5\% kobiet prowadziło firmy przez okres dłuższy niż 3,5 roku” (PARP, 2020: 61). Błędnym więc nie będzie wniosek, iż maleje przewaga mężczyzn nad kobietami w zakresie aktywności przedsiębiorczej.

Do realizacji celu określonego we wstępie niniejszego artykułu warto przywołać obserwacje i wnioski z badań prowadzonych przez naukowców zajmujących się sytuacją kobiet na rynku pracy. Zauważają oni ogólne utrudnienia oraz nierówności, które dotykają kobiet. Wynikają one często z głęboko zakorzenionych stereotypów, wierzeń religijnych, przypisanych dawno ról społecznych, które trudno zmienić. Uważa się np., że kobiety:

- są przeznaczone do roli żon, matek, gospodyń domowych, gdyż są bardziej opiekuńcze, empatyczne, serdeczne, życzliwe,

- są mniej kompetentne od mężczyzn, zwłaszcza w przypadku branż i zawodów przez nich zdominowanych,

- są mniej pewne siebie, nie wierzą we własne możliwości, poszukując pracy myślą o niższych stanowiskach, mają mniejsze oczekiwania,

- nie nadają się na szefów (urodzeni przywódcy to mężczyźni); badania dowodzą, że są one pomijane przy podejmowaniu decyzji o awansach, dlatego im wyższe stanowisko, tym mniej kobiet, bynajmniej nie z powodu niższych kwalifikacji,

- mają problemy z podejmowaniem decyzji,

- są zbyt emocjonalne, „miękkie”, co jest utrudnieniem np. w negocjacjach, stawianiu warunków i wymagań,

- nie radzą sobie w świecie biznesu, rządzącym się prawami, w którym mogą przetrwać tylko najsilniejsi (Piecuch, 2013: 186).

Kobiety na drodze przedsiębiorczości napotykają wiele trudności i barier komplikujących osiągnięcie celu, którym jest np. powołanie do egzystencji gospodarczej własnej firmy. E. Morawiecka wyróżnia następujące bariery:

- społeczne - obejmujące kulturowo ukształtowane stereotypy, wg których powołaniem kobiet jest małżeństwo i macierzyństwo, a miejscem - rodzina i dom. Wśród tak ukształtowanych norm nie ma miejsca na kobietę aktywną, zaradną i przedsiębiorczą;

- edukacyjne - związane z brakiem informacji, głębszej wiedzy na temat tego, jak zakładać, prowadzić i z sukcesem rozwijać swoją firmę; dotyczy to przede wszystkim małych firm, środowisk wiejskich, kobiet o niższym wykształceniu,

- ekonomiczne - przybierające postać stosunkowo wysokich obciążeń podatkowych, niestabilności przepisów, braku etycznych reguł postępowania na rynku, braku dogodnych systemów kredytowania sektora małych i średnich firm,

- instytucjonalne - wyrażane poprzez zbyt dużą ilość czynności koniecznych do zarejestrowania firmy, przerost spraw administracyjnych, niejasne przepisy dotyczące funkcjonowania sektora MŚP, niewydolność sądów, skomplikowane przepisy i częste ich zmiany (Morawiecka, 2012: 132). 
W dostępnych (i przykładowych) dokumentach (np. EUROPA 2020...) i raportach (PARP, 2011) wskazuje się na potrzebę zwiększania aktywności zawodowej kobiet, w tym w formie własnej działalności gospodarczej, podkreślając, że zasadniczym ograniczeniem obecności kobiet na rynku pracy jest brak możliwości pogodzenia obowiązków zawodowych z obowiązkami rodzinnymi, zwłaszcza z funkcjami opiekuńczymi. Wartościuje się więc, że własna działalność gospodarcza, częściej zwana samozatrudnieniem, jest formą zatrudnienia przyjazną rodzinie, ponieważ związana jest z dużym zakresem autonomii określania zasad wykonywania pracy na własny rachunek oraz możliwością decydowania o czasie pracy. Jednakże należy pamiętać i zwrócić na to szczególna uwagę, iż często czas pracy osób samozatrudnionych jest dłuższy od czasu pracy pracowników najemnych (ich czas pracy określa Kodeks pracy), dodatkowo często jest czasem nienormowanym i charakteryzuje się nieregularnym rozkładem. Cechy te jednych zachęcają, innych całkowicie oddalają od planów powołania własnej działalności gospodarczej (Buczak, 2019: 7).

W literaturze nie brak opinii, że rozwój społeczno-gospodarczy nie może być osiągnięty bez aktywnego udziału kobiet we wszystkich aspektach życia, dlatego też istotne jest promowanie różności płci w biznesie (Revenga, Sudhir, 2012: 40).

\section{Determinanty przedsiębiorczości}

Słowo „determinanta” ma wiele synonimów, np. asumpt, bodziec, czynnik, doping, impuls, inicjatywa, inspiracja, motor, motyw, natchnienie, okazja, okoliczność (Synonim. NET, 2021, 20 czerwca). Być zdeterminowanym to być zmotywowanym, a słowo motywacja od łacińskiego słowa movere oznacza 'ruszać z miejsca' (Glinka, Gutkova, 2011: 129). Podobne znaczenie odnajdujemy w łacińskim słowie motus - 'pobudzony, poruszony’. Natomiast „motywacja” definiowana jest jako stan gotowości człowieka do podjęcia określonego działania. Jest to mechanizm psychologiczny, wywołujący reakcję na brak zaspokojenia określonych potrzeb psychicznych, społecznych lub biologicznych, decydujący o dokonywanych wyborach i podejmowanych działaniach (Szewczuk, 1985: 89).

J. Moczydłowska - jedna z autorek definicji przedsiębiorczości - determinanty przedsiębiorczości określiła jako zbiór czynników, które wpływają na inicjatywy założycielskie nowych podmiotów gospodarczych (hamują je lub sprzyjają im) oraz ułatwiają (lub utrudniają) funkcjonowanie i rozwój istniejących przedsiębiorstw. Zatem jest to każdy czynnik, który potencjalnie stanowi szansę lub barierę przedsiębiorczości (Moczydłowska, 2007: 31).

W literaturze przedmiotu wymienia się wiele czynników determinujących zakładanie przez kobiety działalności gospodarczej. Kompleksową propozycję w tym względzie przedstawiły S. Gostkowska-Dźwig i M. Mrozik. Badaczki te wymieniają takie czynniki, jak:

- dążenie do niezależności,

- chęć osiągania wyższych dochodów,

- niezależność finansowa,

- możliwość rozwoju zawodowego,

- negatywne doświadczenia z pracy najemnej,

- sprzyjające warunki na rynku,

- brak innych możliwości zatrudnienia,

- większe możliwości, jakie daje prowadzenie własnego biznesu,

- większa niezależność działania,

- samodzielność w kierowaniu własnym życiem, 
- realizacja osobistych celów,

- możliwość pełniejszego wykorzystania umiejętności,

- osiągnięcie sukcesu zawodowego,

- czynny udział w procesach społecznych,

- poczucie bycia potrzebnym i ważnym, bo osobiście się coś robi,

- dążenie do samodzielności,

- potrzeba godziwych zarobków,

- wyuczony zawód,

- doświadczenie zdobyte w pracy przed założeniem firmy,

- wrodzona przedsiębiorczość,

- zagrożenie bezrobociem,

- nadarzająca się okazja wzbogacenia (Gostkowska-Dźwig, Mrozik, 2013, 115-116).

W celu uwypuklenia motywów zakładania działalności gospodarczej przez kobiety trafnym wydaje się zestawienie ich $\mathrm{z}$ determinantami charakterystycznymi w tym względzie dla mężczyzn. Istotne jest, że w części motywy te są identyczne. Szczegółowe podsumowanie zawiera tabela 1.

Tabela 1. Motywy podejmowania działalności gospodarczej przez kobiety oraz motywy wspólne dla kobiet i mężczyzn

\begin{tabular}{|c|c|}
\hline \multicolumn{2}{|c|}{ Motywy podejmowania działalności gospodarczej } \\
\hline wspólne dla kobiet i mężczyzn & dominujące u kobiet \\
\hline $\begin{array}{l}\text { - dążenie do samodzielności } \\
\text { - potrzeba godziwych zarobków } \\
\text { - wrodzona przedsiębiorczość } \\
\text { - skłonność do ryzyka } \\
\text { - chęć udowodnienia własnej wartości } \\
\text { partnerowi } \\
\text { - brak innych możliwości zarobkowania } \\
\text { - sprzyjające okoliczności na rynku } \\
\text { - zagrożenie bezrobociem } \\
\text { - prestiż, wysoka pozycja społeczna } \\
\text { i zawodowa } \\
\text { - przykład rodziców }\end{array}$ & $\begin{array}{l}\text { - niezależność } \\
\text { - odpowiedzialność za własne decyzje } \\
\text { - możliwość samodzielnego wyznaczania } \\
\text { celów } \\
\text { - bezpieczeństwo finansowe } \\
\text { - możliwość rozwoju finansowego } \\
\text { - realizacja własnych pomysłów } \\
\text { - szansa na ciekawą pracę i satysfakcja z niej } \\
\text { - negatywne doświadczenia z pracy najemnej } \\
\text { - większa pewność pracy } \\
\text { - korzystny, swobodny nienormowany czas } \\
\text { pracy } \\
\text { - możliwość dawania pracy innym } \\
\text { - rodzicielstwo }\end{array}$ \\
\hline
\end{tabular}

Źródło: Opracowanie własne na podstawie: Lisowska, Kasprzak (2008: 181 i 186)

Obok czynników determinujących przedsiębiorcze zachowania kobiet nie sposób w tym miejscu nie wspomnieć o cechach, które posiada, czy lepiej - powinna posiadać, przedsiębiorcza kobieta. Według T. Piecuch kobiety posiadają następujące cechy:

- inicjują działania bardziej ze względu na własny styl życia, zależy im na tym, aby decydować o tym, co robią, o rozkładzie dnia (chcą robić to, co chcą, co lubią i ile chcą),

- są urodzonymi „łącznikami” i z reguły wykorzystują tę cechę do jednoczenia ludzi, inicjowania działania, dbania o dobrą atmosferę w swojej firmie,

- nie zależy im wyłącznie na pieniądzach, główną motywacją do założenia własnej firmy jest pasja, nieodparta chęć działania, niezależność, samodzielność 
i samorealizacja,

- opierają się na swojej wrodzonej kreatywności i intuicji, pokonują przeszkody i podejmują skalkulowane ryzyko, a dodatkowo w stosunku do mężczyzn:

- są bardziej pracowite, rzetelne, dokładne i sumienne,

- są punktualne, zaradne, lepiej zorganizowane (co wynika z konieczności godzenia obowiązków rodzinnych, domowych, z obowiązkami zawodowymi),

- są bardziej obowiązkowe i zainteresowane tym, co robią,

- szybciej pracują, starają się maksymalnie wykorzystać swój czas pracy, by nie musieć pracować po godzinach lub nie zabierać pracy do domu,

- są kreatywne, twórcze i przedsiębiorcze,

- są bardziej nastawione na współdziałanie, na prace grupową, dbają o dobre relacje w grupie,

- są bardziej empatyczne, co wykorzystują w relacjach z ludźmi,

- nie lubią konfliktów, częściej dążą do kompromisów,

- rozsądnie podejmują ryzyko,

- są inteligentne, szybko się uczą i dokształcają,

- są bardziej precyzyjne, dokładne, dociekliwe i cierpliwe (Piecuch, 2013: 192).

\section{Przedsiębiorczość kobiet Wałbrzycha w latach 2013-2020}

Przedstawione powyżej informacje stanowią swego rodzaju wprowadzenie do głównej treści prezentowanego artykułu dotyczącej przedsiębiorczości kobiet, które w latach 2013-2020 założyły działalność gospodarczą w Wałbrzychu. Ponieważ omawiany zakres czasowy zamyka się w przedziale lat 2013-2020, zasadnym wydaje się przedstawienie podstawowych, dostępnych danych statystycznych dotyczących 2020 roku. Zatem według stanu na dzień 30 czerwca 2020 r. liczba ludności Wałbrzycha wynosiła 110603 osoby, z czego 52097 byli to mężczyźni, a 58506 stanowiły kobiety. Do końca pierwszego półrocza 2020 roku urodziło się 357 dzieci, zmarło 882 osób, zawarto 102 małżeństwa (Oficjalny Serwis Miasta Wałbrzycha, 2021, 25 czerwca).

Na koniec lutego 2021 r.: stopa bezrobocia wynosiła 6,4\%, w systemie REGON (według sekcji PKD 2007) zarejestrowanych było 13876 podmiotów gospodarczych, natomiast 8025 osób fizycznych prowadziło działalność gospodarczą (Oficjalny Serwis Miasta Wałbrzycha, 2021, 25 czerwca).

Na podstawie danych pozyskanych z Głównego Urzędu Statystycznego we Wrocławiu, Oddział w Wałbrzychu², określono liczbę zarejestrowanych w latach 2013-2020 podmiotów gospodarczych w systemie REGON z podziałem na płeć właściciela oraz osobowość prawnąa ${ }^{3}$ Szczegółowe dane wzbogacone o łączną liczbę podmiotów zarejestrowanych w Wałbrzychu w poszczególnych latach zobrazowano na rycinie 1.

\footnotetext{
${ }^{2}$ Bazy danych systematycznie pozyskiwane były z GUS-u od 22 marca 2016 r. do 5 kwietnia 2019 r. oraz w dniu 16 marca w2021 r.

${ }^{3}$ Wartość „pozostałe” dla danych za lata 2013-2018 jest sumą takich podmiotów, jak: spółki z o.o., spółki cywilne, spółki jawne, spółki komandytowe, spółki akcyjne; dla danych za lata 2019-2020 do wyżej wymienionych podmiotów zaliczyć należy również: stowarzyszenia, fundacje, szkolne kluby sportowe, biura poselskie, wspólnoty mieszkaniowe, komitety wyborcze, szkoły branżowe pierwszego i drugiego stopnia, żłobki samorządowe, zespoły szkolno-przedszkolne. Różnica wynika ze zmiany organu przygotowującego bazę danych z GUS-u w Wałbrzychu na GUS we Wrocławiu, z czasu pozyskania danych, a także zmiany samego sposobu zbierania danych przez GUS.
} 
Rycina 1. Struktura podmiotów gospodarki narodowej w rejestrze REGON zarejestrowanych w Wałbrzychu w latach 2013-2020 z podziałem na płeć właściciela oraz osobowość prawną podmiotów rejestrujących

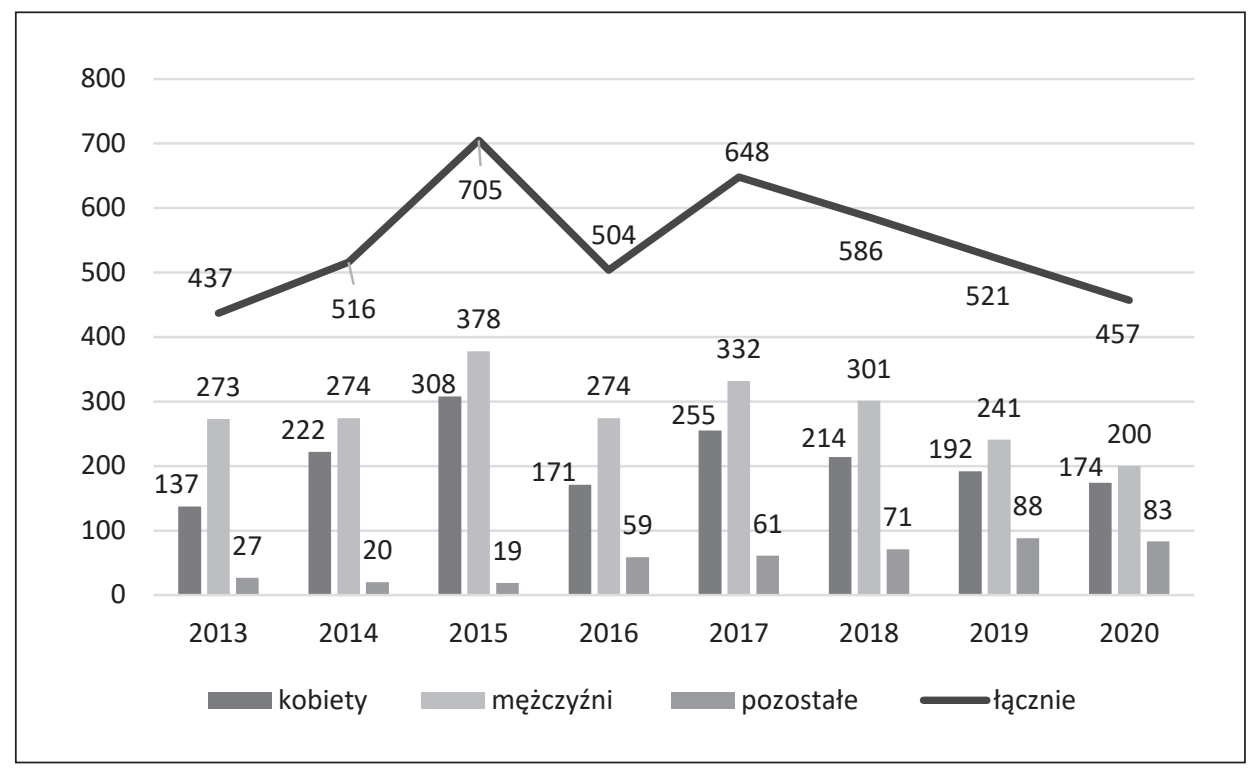

Źródło: Opracowanie własne na podstawie danych pozyskanych z GUS-u od 22 marca 2016 do 5 kwietnia 2019 r. oraz w dniu 16 marca 2021 r.

Wyraźna przewaga w liczbie firm zarejestrowanych przez mężczyzn w Wałbrzychu wpisuje się w ogólną tendencję i zauważalną dominację „męskiej” przedsiębiorczości Ocena ilościowa podmiotów gospodarczych zarejestrowanych w systemie REGON w latach 2013-2020 wskazuje, że miały miejsce względnie wahania liczebności tych podmiotów, przy czym w 2015 r. zaobserwowano największy przyrost rejestracji nowych podmiotów, zarówno wśród mężczyzn, jak i wśród kobiet. Natomiast od 2018 r. zauważyć można spadek liczby ogólnie rejestrowanych działalności gospodarczych, zwłaszcza w zakresie tych zakładanych przez mężczyzn. Warto pokusić się o wniosek dotyczący roku 2020, który na wstępie określono jako początek pandemii COVID-19 w Polsce. Otóż zauważyć można, że cechuje go najniższa liczba rejestracji działalności gospodarczych zarówno w grupie kobiet, jak i w grupie mężczyzn (tu spadek jest zauważalnie wysoki względem poprzednich lat objętych badaniem), natomiast na wysokim poziomie odnotowano grupę działalności „Pozostałe”.

Skumulowaną liczebność zarejestrowanych podmiotów z podziałem na płeć założyciela oraz osobowość prawną podmiotów rejestrujących, zarejestrowanych w Wałbrzychu w analizowanym okresie poddanemu badaniu, przedstawiono na rycinie 2 .

${ }^{4} \mathrm{~W}$ Raporcie o stanie sektora małych i średnich przedsiębiorstw w Polsce PARP znajdujemy zdanie: „samozatrudnieni stanowią $8,1 \%$ pracujących ogółem. Większość z nich, bo ponad dwie trzecie, to mężczyźni (69\%)” (PARP, 2017: 68), a w raporcie Małe i średnie firmy w Polsce - bariery i rozwój: „w 41 proc. firm jednym z właścicieli jest kobieta" (Czerniak, Stefański, 2009: 7). 
Rycina 2. Łączna liczba podmiotów zarejestrowanych w latach 2013-2020 w Wałbrzychu z podziałem na płeć założyciela oraz osobowość prawną podmiotów rejestrujących

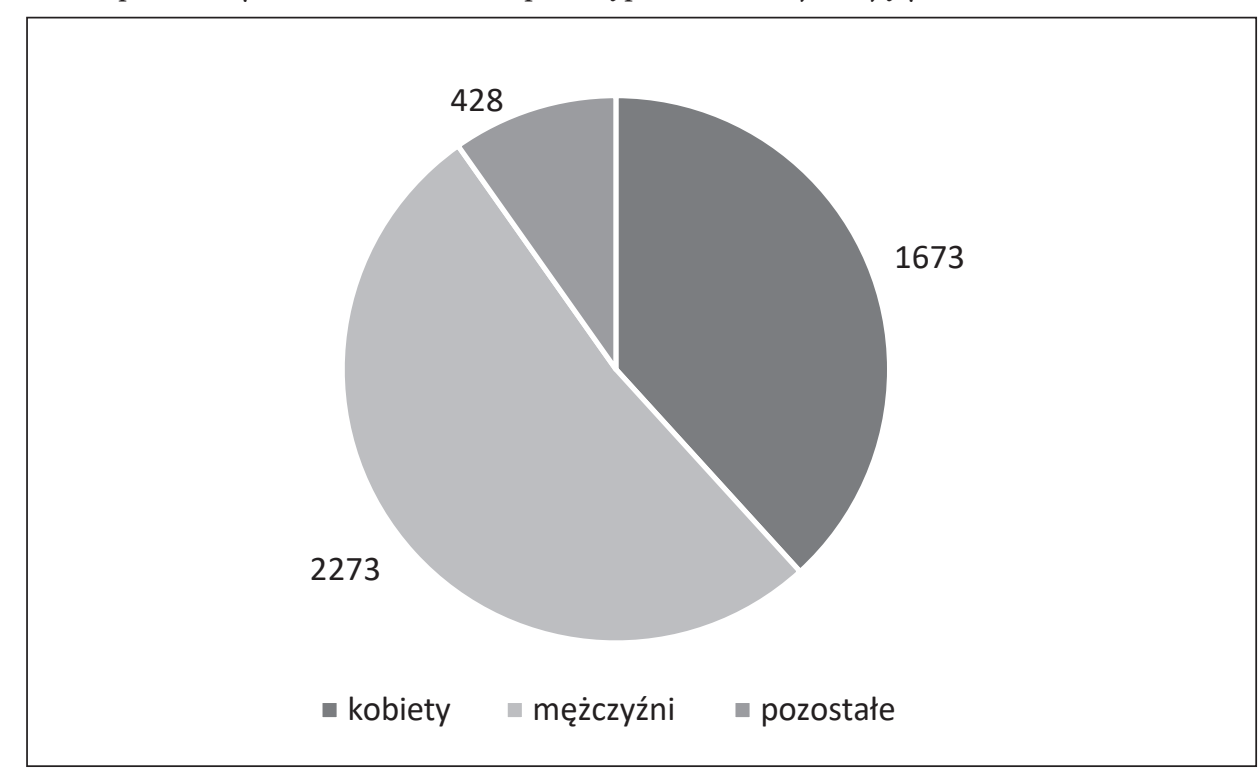

Źródło: Opracowanie własne na podstawie danych pozyskanych z GUS-u od 22 marca 2016 do 5 kwietnia 2019 r. oraz w dniu 16 marca 2021 r.

Przeprowadzona interpretacja materiału statystycznego jest podstawą do bardziej szczegółowych analiz ukierunkowanych na wskazanie profili działalności firm, które zostały założone w Wałbrzychu przez kobiety w latach 2013-2020. Na podstawie zasobów baz danych pozyskanych z GUS-u ustalono liczbę i rodzaje, które zostały zarejestrowane przez kobiety w Wałbrzychu w poszczególnych latach omawianego okresu. Weryfikacji dokonano, grupując kody $\mathrm{PKD}^{5}$ firm. Uzyskane wyniki pozwalają stwierdzić, że poziom przedsiębiorczości kobiet w Wałbrzychu wydaje się wpisywać w krajową tendencję, ponieważ w latach 2013-2020 kobiety założyły mniej firm niż mężczyźni, przy czym w latach 2019-2020 różnice te były zauważalnie mniejsze niż w latach poprzedzających, objętych badaniem. Zauważyć można również, że wzrost liczby podmiotów, które zarejestrowały kobiety w Wałbrzychu, nie łączy się ze wzrostem liczby rodzajów prowadzonych aktywności. Wręcz przeciwnie, przy spadku liczby rejestrowanych działalności gospodarczych liczba rodzajów działalności liczonych wg kodów PKD nie ulega gwałtownemu zmniejszeniu (por. rycina 3). Można wysnuć więc wniosek, że w omawianym okresie zainteresowania przedsiębiorcze kobiet wypadały w tych samych ramach zawodowych.

Istotnym krokiem do realizacji tematu opracowania było wskazanie powtarzalności rejestracji konkretnych profili działalności firm zakładanych przez kobiety, np. liczba 4

\footnotetext{
${ }^{5}$ Po wstąpieniu Polski do Unii Europejskiej nadszedł czas na zmiany związane z koniecznością dostosowania polskiego prawa względem prawa unijnego, czego skutkiem było wprowadzenie nowego grupowania działalności w postaci Polskiej Klasyfikacji Działalności PKD 2004. Nowa klasyfikacja miała zastosowanie w statystyce, ewidencji i dokumentacji oraz rachunkowości, a także w urzędowych rejestrach i systemach informacyjnych administracji publicznej - na podstawie Ustawy z 29 czerwca 1995 r. o statystyce publicznej oraz Rozporządzenia Rady Ministrów z dnia 20 stycznia 2004 r. w sprawie Polskiej Klasyfikacji Działalności (PKD).
} 
Rycina 3. Liczba rodzajów działalności liczonych wg kodów PKD w zestawieniu z łączną liczbą działalności gospodarczych zarejestrowanych przez kobiety w Wałbrzychu w latach 2013-2020

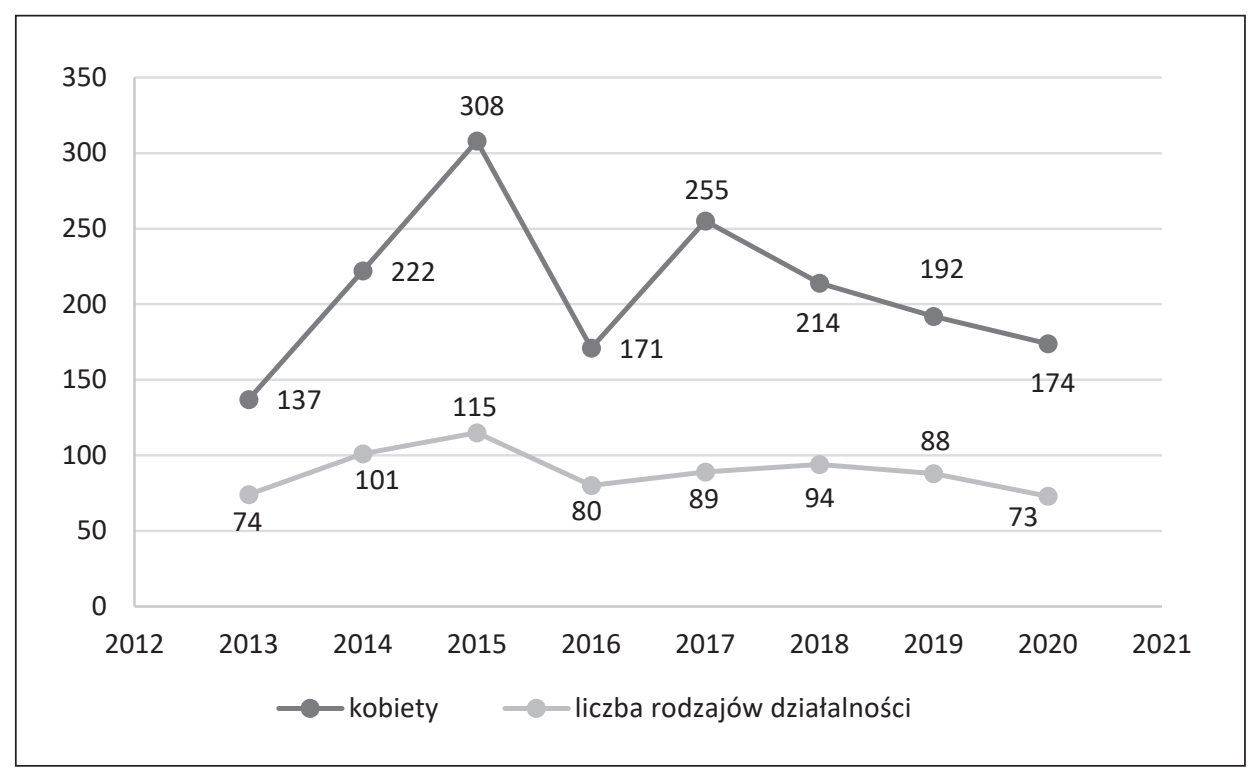

Źródło: Opracowanie własne na podstawie danych pozyskanych z GUS-u od 22 marca 2016 do 5 kwietnia 2019 r. oraz w dniu 16 marca 2021 r.

w skrzyżowaniu pozycji „2015” i „powtarzalność rejestracji powyżej 10 i 10” oznacza, że w 2015 r. były 4 kody PKD, które zostały zarejestrowane przez kobiety 10 lub więcej razy, czyli zarejestrowano 10 lub ponad 10 firm z jednym kodem PKD i 10 lub więcej niż 10 firm z innym (jednakowym) kodem PKD. Podsumowanie tych eksplikacji zawarto w tabeli 2.

Tabela 2. Powtarzalność rodzajów działalności wg kodów PKD firm założonych przez kobiety w Wałbrzychu w latach 2013-2020

\begin{tabular}{|l|c|c|c|c|c|c|c|c|}
\hline $\begin{array}{c}\text { Powtarzalność } \\
\text { rejestracji }\end{array}$ & $\mathbf{2 0 1 3}$ & $\mathbf{2 0 1 4}$ & $\mathbf{2 0 1 5}$ & $\mathbf{2 0 1 6}$ & $\mathbf{2 0 1 7}$ & $\mathbf{2 0 1 8}$ & $\mathbf{2 0 1 9}$ & $\mathbf{2 0 2 0}$ \\
\hline powyżej 10 i 10 & 2 & 3 & 4 & 1 & 3 & 2 & 2 & 1 \\
\hline $\begin{array}{l}\text { powyżej 5 i 5, } \\
\text { ale mniej niż 10 }\end{array}$ & 0 & 7 & 14 & 6 & 11 & 6 & 4 & 7 \\
\hline 4 rejestracje & 2 & 5 & 7 & 5 & 8 & 4 & 0 & 2 \\
\hline 3 rejestracje & 10 & 9 & 10 & 7 & 11 & 10 & 6 & 12 \\
\hline 2 rejestracje & 17 & 18 & 21 & 14 & 13 & 17 & 24 & 14 \\
\hline 1 rejestracja & 43 & 59 & 59 & 47 & 43 & 55 & 52 & 37 \\
\hline
\end{tabular}

Źródło: Opracowanie własne na podstawie danych pozyskanych z GUS-u od 22 marca 2016 do 5 kwietnia 2019 r. oraz w dniu 16 marca 2021 r.

Powyższe zestawienie pozwala zauważyć duże rozdrobnienie w kategoriach rejestrowanych przez kobiety działalności gospodarczych w Wałbrzychu w latach 2013-2020. Świadczą o tym liczby pojedynczych rejestracji w sekcji PKD w poszczególnych latach. Wskazywać może to na pomysłowość, kreatywność i z pewnością - wykorzystywanie 
przez kobiety szans, które pojawiają się na rynku. Różnorodność działalności gospodarczych świadczyć może również o poszukiwaniu okazji do wykorzystania posiadanego doświadczenia lub nabytej wiedzy, daje szansę na przebicie się spośród jednakowych, podobnych do siebie firm. Oryginalne sposoby realizacji zadań pozwalają zdobyć wymagających klientów i zbudować pozycję w konkretnym zakresie działalności gospodarczej. Niejednokrotnie o rejestracji konkretnego rodzaju działalności decyduje również umiejętność dostrzeżenia okazji, niszy na rynku, zapotrzebowania „chwili” na dany rodzaj produktów czy usług. To w dzisiejszych czasach ogromny potencjał rozwojowy.

W omawianym zakresie czasowym największa liczba rejestracji miała miejsce w każdym roku poddanym analizie dla działalności oznaczonej symbolem PKD 9602Z, przypisanym do profilu: Fryzjerstwo i pozostałe zabiegi kosmetyczne. W pięciu analizowanych latach: 2014, 2015, 2017, 2018 i 2019, powtórzyła się rejestracja działalności oznaczonej numerem PKD 4791Z, czyli Sprzedaż detaliczna prowadzona przez domy sprzedaży wysyłkowej lub Internet. Z kolei w latach 2014 i 2017 wśród działalności zarejestrowanych 10 lub więcej razy powtórzył się symbol PKD 4771Z, przypisany do Sprzedaży detalicznej odzieży prowadzonej w wyspecjalizowanych sklepach ${ }^{6}$.

Szczegółowe zestawienie wymienionych powyżej profili działalności oraz pozostałych, które zostały zarejestrowane przez kobiety w Wałbrzychu w latach 2013-2020, a których liczba rejestracji równa była lub przekroczyła 10, przedstawiono w tabeli 3.

Łączną liczbę rejestracji firm (główne profile), z uwzględnieniem numerów PKD, których rejestracja w latach 2013-2018 była równa i wyższa od 10, zobrazowano na rycinie 4.

Z powyższego zestawienia można wnioskować, że w latach 2013-2020 w Wałbrzychu kobiety najchętniej rozpoczynały działalność gospodarczą, (najpewniej) wykorzystując wiedzę zawodową (fryzjerstwo i kosmetyka) oraz, że korzystały chętnie ze zdobyczy technologicznych (nieustający rozwój Internetu) oraz ogólnoświatowego trendu dokonywania zakupów „w sieci” bez wychodzenia z domu i w ten sposób rozwijały firmy (dostrzegły szansę dotarcia do odbiorców swoich produktów i usług poza granicami miasta czy kraju). W latach poddanych obserwacji tylko 2015 r. wyraźnie różnił się w łącznej liczbie zarejestrowanych aktywności (w sekcji PKD), ponieważ utworzono znaczącą liczbę działalności specjalistycznych: księgowo-rachunkowych oraz gastronomicznych. Co ciekawe, rok 2020 - obarczony rozwojem pandemii COVID-19, w tym obostrzeniami sanitarnymi, lockdownem gospodarki i koniecznością przestrzegania dystansu społecznego, szczególnie dotkliwego dla branż opierających się na bezpośredniej obsłudze i kontakcie z klientem - nie różnił się od poprzednich lat objętych badaniem pod względem profilu działalności najczęściej rejestrowanej przez kobiety w Wałbrzychu. W 2020 r. najczęściej rejestrowanym rodzajem działalności gospodarczej wśród wałbrzyskich kobiet było fryzjerstwo i pozostałe zabiegi kosmetyczne. Bez dodatkowych badań trudno jednak wskazać przyczyny takiego zdarzenia.

\footnotetext{
${ }^{6}$ Podczas rejestracji działalności gospodarczej przedsiębiorca ma obowiązek wskazać kod działalności wiodącej, z którym zostaje wpisany do rejestru REGON. Ma również prawo oznaczyć kody PKD pozostałych swoich aktywności, a także ich podgrupy i rozszerzenia. Dane pozyskane z GUS-u od 22 marca 2016 do 5 kwietnia 2019 oraz w dniu 16 marca 2021 r. opierają się wyłącznie na numerach PKD określających wiodący profil działalności (grupa podstawowa), bez podgrup i rozszerzeń.
} 
Tabela 3. Firmy założone przez kobiety w Wałbrzychu w latach 2013-2020, których liczba rejestracji była równa lub większa niż 10 wraz z opisem

\begin{tabular}{|c|c|c|}
\hline Numer PKD & Opis profilu działalności & $\begin{array}{l}\text { Liczba } \\
\text { rejestracji }\end{array}$ \\
\hline \multicolumn{3}{|c|}{ ROK 2013} \\
\hline $4711 \mathrm{Z}$ & $\begin{array}{l}\text { Sprzedaż detaliczna prowadzona w niewyspecjalizowanych } \\
\text { sklepach z przewagą żywności, napojów i wyrobów } \\
\text { tytoniowych }\end{array}$ & 10 \\
\hline $9602 Z$ & Fryzjerstwo i pozostałe zabiegi kosmetyczne & 12 \\
\hline \multicolumn{3}{|c|}{ ROK 2014} \\
\hline $4771 \mathrm{Z}$ & $\begin{array}{l}\text { Sprzedaż detaliczna odzieży prowadzona } \\
\text { w wyspecjalizowanych sklepach }\end{array}$ & 10 \\
\hline $4791 \mathrm{Z}$ & $\begin{array}{l}\text { Sprzedaż detaliczna prowadzona przez domy sprzedaży } \\
\text { wysyłkowej lub Internet }\end{array}$ & 12 \\
\hline $9602 Z$ & Fryzjerstwo i pozostałe zabiegi kosmetyczne & 16 \\
\hline \multicolumn{3}{|c|}{ ROK 2015} \\
\hline $4791 \mathrm{Z}$ & $\begin{array}{l}\text { Sprzedaż detaliczna prowadzona przez domy sprzedaży } \\
\text { wysyłkowej lub Internet }\end{array}$ & 11 \\
\hline $5610 \mathrm{~A}$ & Restauracje i inne stałe placówki gastronomiczne & 11 \\
\hline $6920 Z$ & Działalność rachunkowo-księgowa; doradztwo podatkowe & 11 \\
\hline $9602 Z$ & Fryzjerstwo i pozostałe zabiegi kosmetyczne & 29 \\
\hline \multicolumn{3}{|c|}{ ROK 2016} \\
\hline $9602 Z$ & Fryzjerstwo i pozostałe zabiegi kosmetyczne & 21 \\
\hline \multicolumn{3}{|c|}{ ROK 2017} \\
\hline $4771 \mathrm{Z}$ & $\begin{array}{l}\text { Sprzedaż detaliczna odzieży prowadzona } \\
\text { w wyspecjalizowanych sklepach }\end{array}$ & 10 \\
\hline $4791 \mathrm{Z}$ & $\begin{array}{l}\text { Sprzedaż detaliczna prowadzona przez domy sprzedaży } \\
\text { wysyłkowej lub Internet }\end{array}$ & 12 \\
\hline $9602 Z$ & Fryzjerstwo i pozostałe zabiegi kosmetyczne & 29 \\
\hline \multicolumn{3}{|c|}{ ROK 2018} \\
\hline $4791 \mathrm{Z}$ & $\begin{array}{l}\text { Sprzedaż detaliczna prowadzona przez domy sprzedaży } \\
\text { wysyłkowej lub Internet }\end{array}$ & 10 \\
\hline $9602 Z$ & Fryzjerstwo i pozostałe zabiegi kosmetyczne & 30 \\
\hline \multicolumn{3}{|c|}{ ROK 2019} \\
\hline $4791 Z$ & $\begin{array}{l}\text { Sprzedaż detaliczna prowadzona przez domy sprzedaży } \\
\text { wysyłkowej lub Internet }\end{array}$ & 11 \\
\hline $9602 Z$ & Fryzjerstwo i pozostałe zabiegi kosmetyczne & 36 \\
\hline \multicolumn{3}{|c|}{ ROK 2020} \\
\hline $9602 Z$ & Fryzjerstwo i pozostałe zabiegi kosmetyczne & 21 \\
\hline
\end{tabular}

Źródło: Opracowanie własne na podstawie danych pozyskanych z GUS-u od 22 marca 2016 do 5 kwietnia 2019 r. oraz w dniu 16 marca 2021 r.

\section{Podsumowanie}

Każda zarejestrowana działalność gospodarcza może być wyrazem dostrzeżonej szansy zarobkowania, rozwoju osobistego, koniecznością, przymusem, dodatkiem do pracy na 
Rycina 4. Skumulowana liczba rejestracji firm (z uwzględnieniem numerów PKD), które założyły kobiety w Wałbrzychu w latach 2013-2020

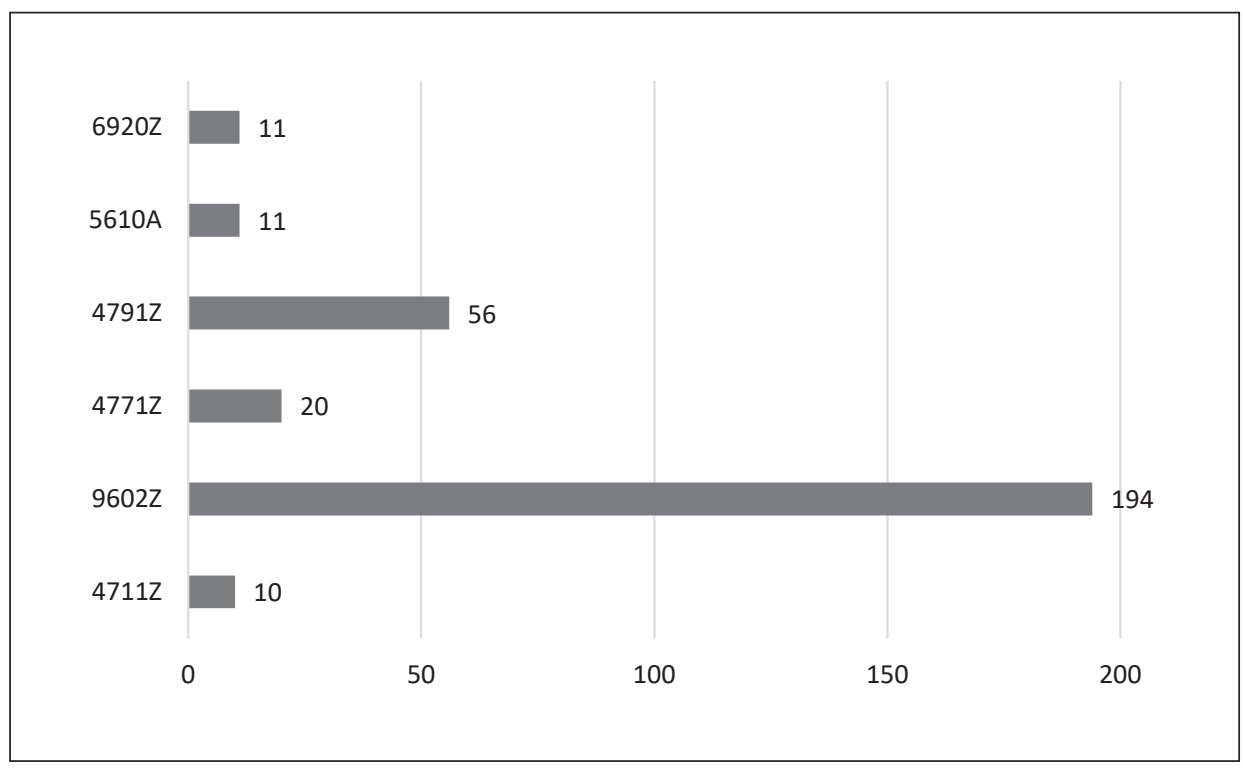

Źródło: Opracowanie własne na podstawie danych pozyskanych z GUS-u od 22 marca 2016 do 5 kwietnia 2019 r. oraz w dniu 16 marca 2021 r.

etacie. Powodów może być tyle, ile jest kobiet, które podjęły to ryzyko i powołały do życia gospodarczego swoje firmy, zarządzają nimi, kierują ich rozwojem i prezentują klientom ofertę produktowo-usługową. To m.in. od ich zaangażowania, pomysłowości, zaradności zależy, czy i na jak długo zarejestrowana działalność pozostanie na rynku, czy będzie miała klientów i odbiorców swoich produktów oraz usług. Innymi czynnikami, które z pewnością wpływają na obecność danej działalności gospodarczej na rynku, są: aktualna koniunktura, zapotrzebowanie na konkretny typ i rodzaj produktów oraz usług, zamożność klientów, światowe i krajowe trendy czy chociażby nieprzewidywane zjawiska, takie jak pandemia COVID-19, katastrofy naturalne czy zablokowanie światowego kanału transportowego żeglugi morskiej.

Celem artykułu nie była identyfikacja powodów zakładania działalności przez przedsiębiorcze kobiety Wałbrzycha w latach 2013-2020, choć część opracowania poświęcona została zagadnieniu determinant działań przedsiębiorczych wśród kobiet. Założono dwa cele. Celem pierwszym była próba stworzenia profilu działania założonych przez kobiety podmiotów gospodarczych. Zamierzenie to zostało spełnione, ponieważ przeprowadzone analizy materiału badawczego wskazały jeden, konkretny rodzaj działalności, który w każdym poddanym analizie roku kalendarzowym był najczęściej rejestrowany przez kobiety w Wałbrzychu: 9602Z - Fryzjerstwo i pozostałe zabiegi kosmetyczne. Wykazane zostały również inne, powtarzające się w pięciu z ośmiu analizowanych lat, profile działalności, tj. Sprzedaż detaliczna prowadzona przez domy sprzedaży wysyłkowej lub Internet (numer PKD 4791Z) oraz Sprzedaż detaliczna odzieży prowadzona w wyspecjalizowanych sklepach (numer PKD 4771Z) - ten zakres działalności rejestrowany był powtarzalnie $\mathrm{w}$ dwóch $\mathrm{z}$ ośmiu lat $\mathrm{z}$ okresu poddanego badaniu. 
Celem drugim była próba określenia, czy pandemia COVID-19 (rozwijająca się w Polsce od marca 2020 r.) miała wpływ na przedsiębiorcze decyzje mieszkanek Wałbrzycha, ze szczególnym uwzględnieniem liczby i rodzajów założonych przez nie firm. Ten aspekt został również wnikliwie rozważony i pozwolił na sformułowanie wniosku, iż istotnie zmniejszeniu, względem lat poprzedzających 2020 r., a objętych badaniem, uległa liczba zarejestrowanych działalności gospodarczych - zarówno w ogólnej liczbie, jak i z podziałem na płeć założyciela. Tu można wysnuć wniosek, że rozwój pandemii mógł wpłynąć na rezygnację z zamiarów założenia działalności lub odłożenia tej decyzji w czasie. Jednak profil działalności (oparty na konkretnym numerze PKD) najczęściej rejestrowanej był identyczny jak w latach 2013-2019 - 9602Z - Fryzjerstwo i pozostałe zabiegi kosmetyczne.

Ogólnoświatowy kryzys spowodowany pojawieniem się pandemii COVID-19 wpłynął na codzienność i wciąż definiuje rzeczywistość każdego z nas. Życie społeczne, gospodarcze, procesy ekonomiczne czy zwykłe „ludzkie” sprawy długo jeszcze nie wrócą, o ile wrócą w ogóle, do sytuacji sprzed pandemii. Gdy wirus SARS-CoV-2, powszechnie nazywany koronawirusem, rozprzestrzenił się w całym świecie, podjęto działania mające ratować ludzkość, gospodarki i finanse poszczególnych państw czy światowy handel. Wszystkie dostępne siły i środki kierowane były do walki z tym niewidzialnym wrogiem, co spowodowało, że w 2020 r., ucząc się dopiero sposobów postępowania, wstrzymywano pewne działania, odkładano je w czasie, np. rozpatrywanie wniosków o przyznanie środków na rozpoczęcie działalności gospodarczej dla osób bezrobotnych zarejestrowanych w urzędach pracy czy pozyskiwanie zewnętrznych funduszy dla nowo powstałych firm. Wielu przyszłych przedsiębiorców, którzy początek swej działalności widzieli w takim właśnie finansowaniu, musiało z założenia działalności zrezygnować. Nie będzie więc błędem stwierdzenie, że może być to jeden z czynników wpływających na zmniejszoną liczbę zarejestrowanych działalności gospodarczych w Wałbrzychu w 2020 r., w tym działalności zarejestrowanych tylko przez kobiety. By pozyskać szczegółowe wnioski w tym zakresie, niezbędne będą dalsze szczegółowe badania.

Przedstawione analizy z pewnością stanowią podwalinę pod kolejne opracowania z zakresu przedsiębiorczych zachowań kobiet. Niniejszy artykuł miał za zadanie przybliżenie czytelnikowi profili biznesowych zainteresowań przedsiębiorczych kobiet, które w latach 2013-2020 zarejestrowały działalności gospodarcze w Wałbrzychu, z uwzględnieniem wpływu pandemii COVID-19. Oba założone cele zostały spełnione.

Literatura

References

Biznes.gov.pl. (2021, 25 czerwca). Wyszukiwarka kodów PKD. https://www.biznes.gov.pl/pl/tabela-pkd Buczak, A. (2019). Instytucje otoczenia biznesu a zakładanie działalności gospodarczej przez kobiety. Rozprawa doktorska. Jelenia Góra: UE we Wrocławiu.

EUROPA 2020 - Strategia na rzecz inteligentnego i zrównoważonego rozwoju sprzyjajacego właczeniu społecznemu. (2010). Bruksela: UE.

Glinka, B., Gudkova, S. (red.). (2011). Przedsiębiorczość. Warszawa: Wydawnictwo Wolters Kluwer.

GUS. (2021, 22 marca). Standardowe klasyfikacje i nomenklatury. Pozyskano z: http://www.stat.gov.pl/ Klasyfikacje 
Gostkowska-Dźwig, S., Mrozik, M. (red.). (2013). Kreatywność i potencjał kobiet w zakresie przedsiębiorczej postawy-wybrane problemy.W:B. Skowron-Grabowska(red.), Rozwójprzedsiębiorczości. Częstochowa: Sekcja Wydawnictw Wydziału Zarządzania Politechniki Częstochowskiej.

Lisowska, E., Kasprzak, R. (red.). (2008). Zarządzanie mikroprzedsiębiorstwem. Podręcznik dla przedsiębiorczej kobiety. Warszawa: SGH.

Moczydłowska, J. (2007). Zarządzanie kompetencjami zawodowymi a motywowanie pracowników. Warszawa: Difin.

Morawiecka, E. (2012). Psychospołeczne uwarunkowania przedsiębiorczości kobiet: bariery, ograniczenia, wyzwania. W: H. Kościelniak (red.), Przedsiębiorczość - szanse i wyzwania. Częstochowa: Sekcja Wydawnictw Wydziału Zarządzania Politechniki Częstochowskiej.

Oficjalny Serwis Miasta Wałbrzycha. (2021, 25 czerwca). Wałbrzych w statystyce. Pozyskano z: https:// um.walbrzych.pl/pl/page/walbrzych-w-statystyce-0-

Piecuch, T. (2013). Przedsiębiorczość. Podstawy teoretyczne. Warszawa: Wydawnictwo C.H. Beck.

PARP. (2011). Raport Państwowej Agencji Rozwoju Przedsiębiorczości. Przedsiębiorczość kobiet w Polsce. Warszawa: PARP.

PARP. (2017). Raporto stanie sektora matych iśrednich przedsiębiorstww Polsce. Warszawa: Wydawnictwo Naukowe Instytutu Technologii Eksploatacji - Państwowego Instytutu Badawczego.

PARP. (2018). Raport z badania GEM 2017 - 2018. Warszawa: PARP oraz Uniwersytet Ekonomiczny w Katowicach.

PARP. (2020). Raport z badania Global Entrepreneurship Monitor Polska 2020. Warszawa: PARP oraz Uniwersytet Ekonomiczny w Katowicach.

Revenga, A., Sudhir, S. (red.). (2012) Empowering Women is Smart Economics March 2012/49(1). Finance \& Development.

Rozporzadzenie Rady Ministrów z dnia 20. stycznia 2004 r. w sprawie Polskiej Klasyfikacji Działalności (PKD). Dz.U. 2004 nr 33, poz. 289.

Czerniak, A., Stefański, M. (2021, 5 maja). Małe i średnie firmy w Polsce - bariery i rozwój. Polityka Inside. Pozyskano z: https://www.politykainsight.pl/_resource/multimedium/20091348

Synonim.NET (2021, 20 czerwca). Determinanta. Pozyskano z: https://synonim.net/synonim/determinanta

Szewczuk, W. (red.). (1985). Stownik psychologiczny. Warszawa: Wiedza Powszechna.

Ustawa z 29 czerwca 1995 r. o statystyce publicznej. Dz.U. z 2019 r., poz. 649.

Agata Buczak, dr, Uniwersytet Ekonomiczny we Wrocławiu, Wydział Ekonomii i Finansów, Katedra Mikroekonomii i Ekonomii Instytucjonalnej. Doktor w dziedzinie nauk społecznych, w dyscyplinie ekonomia i finanse. Przedmiotem jej zainteresowań naukowych są: aktywność ekonomiczna kobiet, uwarunkowania społeczno-ekonomiczne przedsiębiorczej działalności człowieka, bariery i czynniki hamujące zachowania przedsiębiorcze, ze szczególnym uwzględnieniem przedsiębiorczości kobiet. Obszar badań stanowią: działalność instytucji otoczenia biznesu, sytuacja kobiet na rynku pracy, płacy oraz dostępu do wsparcia działań przedsiębiorczych, współpraca biznesu z otoczeniem społeczno-gospodarczym. Autorka zwraca szczególną uwagę na kwestie związane z rozwojem przedsiębiorczości kobiet i koniecznością wspierania ich dążeń oraz działań przedsiębiorczych.

Agata Buczak, PhD, Wroclaw University of Economics and Business, Faculty of Economics and Finance, Department of Microeconomics and Institutional Economics. $\mathrm{PhD}$ in the field of social sciences, in the discipline of economics and finance. The subject of her scientific interests are: economic activity of women, socio-economic determinants of entrepreneurial activity, barriers and factors inhibiting entrepreneurial behaviour, with particular emphasis on female entrepreneurship. The research area includes: the activities of business environment institutions, the situation of women on the labour market, pay and access to support for entrepreneurial activities, cooperation between business and the social and economic environment. The author pays special 
attention to issues related to the development of female entrepreneurship and the need to support their aspirations and entrepreneurial activities.

ORCID: https://orcid.org/0000-0003-4674-3099

\section{Adres/Address:}

Uniwersytet Ekonomiczny we Wrocławiu

Katedra Mikroekonomii i Ekonomii Instytucjonalnej

ul. Komandorska 118/120

53-345 Wrocław

e-mail: agata.buczak@ue.wroc.pl 